\title{
Business Open Big Data Analytics to Support Innovative Leadership and Management Decision in Canada
}

http://doi.org/10.21272/bel.4(2).56-74.2020

\section{Nadia Delanoy}

PhD, MBA, M.Ed., Business Department, University of Calgary, Calgary, Alberta, Canada

Karina Kasztelnik, ORCID: https://orcid.org/0000-0002-1090-3700

PhD, MBA, CPA, CTP, Senior Dissertation Chair, Grand Canyon University, College of Doctoral Studies, Washington, DC, USA

\section{Abstract}

This paper summarizes how social media and other technologies continue to proliferate; the shifting economic landscape will precipitate more adaptive approaches for managers attempting to understand the multidimensional virtual aspects of communication with the artificial intelligence aspect. Also, we discover the different existing support of big data analytics to make the rational business decision. The methodology is the systematization literature sources within this context and approaches for underlining approach to open big data analytics and support innovative leadership decisions in Canada. The paper is carried out in the following logical sequence to gain an understanding on how customer relations managers could utilize social media within a data analytics frame from scholar and practitioner perspectives. This literature research review original paper outlines the main themes including the role of social media, the experiences of using data analytics for customer relations management, and the notion that customer-centric technologies could change the dynamic of understanding customer intentions, leadership decisions and introduce the innovative management with using the big data analytics in place. The results of the critical thinking with analysis both authors can be useful for any business around the World that would like to start using Artificial Intelligence to support innovative management decisions. The emergent themes that were highlighted based on the realities of customer relations management may be significant to how the integration of social media feedback resulting from crowdsourcing in addition to existing data analytics could better position organizations in this evolving world. The implications of linking innovative management processes such as demographic analysis, platform understanding, and communication methods together is crucial for any public business with the global impact. Finally, the understanding of innovative management in a social media era and understanding how customers utilized open big data analytics sources could help leadership practices across industries around the World.

Keywords: Big Data Analytics, Innovative Leadership, Management of Social Media, Open Sources.

JEL Classification: O32, 035, 036, 032, 030, D70, D79, D81.

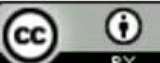

Cite as: Delanoy, N., Kasztelnik, K. (2020). Business Open Big Data Analytics to Support Innovative Leadership Decision in Canada. Business Ethics and Leadership, 4(2), 56-74. http://doi.org/10.21272/bel.4(1).56-74.2020.

(C) The Authors, 2020. This article is published with open access at Sumy State University.

\section{Introduction}

In order to understand this phenomenon, I framed the literature search into sections of customer relationship management and social media from both a scholar and practitioner lens to ensure there was a fulsome examination of the existing practices and where the advancements in Web 2.0 have manifested in the literature from 2013 to 2018. Additionally, searching for branding community development within a communication and marketing strategy association was completed in order to ascertain what the contemporary considerations have been within organizations across sectors. The reason for not limiting the scope of literature was that this technology is continuing to develop, and the literature was not saturated within any sector. For example, the implications of social media as a tangible strategic choice was considered by researchers and practitioners alike (Grossberg, 2018; Holtzblatt \& Tierney, 2011). I also explored literature which explained the historical and current assessments of customer relations management and what shifts researchers and practitioners needed to occur for organizations to more aptly leverage social media. 
The searches were completed utilizing alerts and real-time searches across multiple databases in the Walden University online library, Academic Search Complete, ProQuest Central, SAGE Premier, Business Complete and Science Direct. Moreover, Google Scholar identified articles from reference lists that pertained to the phenomenon of study. The Gartner Group and articles from Forbes Magazine provided the contemporary context within the field; these entities are considered think tanks and are as credible as real-world or expert points of research outside of scholarly peer-reviewed works.

Big Data Analytics and Crowdsourcing Frame: Case Examples. As the literature indicated from the scholarly business journal publications such as Gartner Group and practitioner journals such as Customer Relations Management, big data analytics and crowdsourcing methods such as social media provide both context within the data and a voice for consumers (Adams, 2014). Based on the cases that were evaluated, the current state of social media and customer relationship practices are being realized as the technology and platforms evolve. For example, traditional big data and analytics are complemented by extended data points which include crowdsourcing within social media (Orenga \& Chalmet, 2016; Aquino, 2015). Additionally, there were significant benefits to using big data analytics in accordance with social media for CRM frameworks, which helped justify for companies to be more adaptive. (Smilansky, 2015).

Many organizations that have not invested in tools or IT infrastructure development that engage with crowdsourcing risk omitting contextual facets which narrative data may illuminate (Kunz et al., 2017). Marcus and Davis (2014) and Rizkallah (2017), when they analyzed the inherent problems with big data approaches, identified the importance of an integrated approach to customer relationship management. The Hume problem, as described by Bontempi (2016) addressed the importance of gathering information that reflects the human context and discerns that inductive practices can support customer relationship management systems. Moorthy et al. (2015) provided a powerful case which depicts the integration of big data and social media as data points within a more holistic approach in the communications industry; highlighting the interplay between traditional data analytics and the incorporation of social media support this studies case.

Kunz et al. (2017) provided an analysis of customer engagement within a big data context and reaffirms the merits of social media as indicated in the previous section. This article provided greater context on how companies evaluate and use information to manage customer engagement. This study brought to light some of the important reasons why customers engage or choose not to and how that choice impacts CRM practices. The bridging of relational factors provided more customer-centricity and the opportunity for organizations to more fully inform their marketing, communications and branding strategies and consider how to more readily equalize feedback from consumers (Moorthy et al., 2015). With the proliferation of social media and handheld devices which in some ways act as personal computers, access to crowdsourcing is equalized in relative terms for customers and businesses alike; communication and the ability to participate in online communities related to product or service offerings is easier than it has ever been (Liu et al., 2017; Lu et al., 2017; Adams, 2014).

Despite these changes, digitization is lacking in many organizations the upper echelons of leadership may not see the real time advantages of the initial sunk costs because of fiscal prioritization; an entire infrastructure shift can be immensely expensive (BCG, 2018). Moreover, organizations have yet, at scale, to invest and subsequently integrate social media within their current data analytics approaches with confidence (Agnihotri, Trainor, Itani, \& Rodriguez, 2017). The benefits of seeing small and medium size companies utilizing social media within a data analytics frame could help others appreciate or understand the benefits of this bourgeoning technological reality (Courchesne, Ravanas \& Pulido, 2019; Kim, Kim, Wang, \& Kim, 2016; Zahoor \& Quereshi, 2017). For example, many South Pacific and Asian oriented case studies indicated that companies leveraged social media from a luxury market perspective, providing credence for the advancement of CRM with social media within a big data context (Pentina, Guilloux, \& Mixer, 2018). Other cases from companies in the Middle East showcased the benefits of social media and CRM practices and reaffirmed that the usage could support a greater understanding of customer behaviors and purchasing intentions, leverage customer relationship management for optimization, and organizational effectiveness (Malthouse, Haenlein, Skiera, Wege, \& Zhang, 2013).

Data point confirmation and cleaning are opportunities within customer relations management and social media approaches because they can provide greater clarity and underpin a common organizational language. Additionally, the data triangulation approaches such as data overlay, multiple data points from internal and external pulls can further support a co-creation value framework within a branding community orientation and more customer centric practices (Parsons \& Lepkowski-White, 2018). 
Customer Intentions: Role of Social Media in Customer Relationship Management. Within the current literature, the proliferation of social media within the customer relationships realm reflected the continual advancements in scholarly and practitioner fields. Social media transcends traditional social, economic and in some way's political boundaries within e-commerce, which creates powerful opportunities for customer relations managers pertaining to communication, inputs, iterative practice, performance and the like (Erkan \& Evans, 2016). Initially in the infancy of social media and customer relationship management, researchers and practitioners theorized about the possibilities and constraints to which social media would lead. Now, as social media continues to develop, cases of use and restructuring of infrastructure, as well as pragmatic implications can be assessed in accordance with theoretical discussion (Haenlein \& Libai, 2017). As Trefler (2014) and Akar and Dalgic (2018) reinforced, it was the intent of social media within a customer relationship management that needs to be considered holistically; the implications of online consumer behaviors and purchase intentions were reflected within this medium and within the context of crowd sourcing methods which include platforms such as Facebook, Instagram, LinkedIn and the like. These implications are the anchor to the gap established was established in this study. What was missing was an examination of the realities of social media, customer relationship management as well as how social media was navigated and informed customer relations. The gap in implementation and understanding, and the ability to manage within these platforms is evolving at a steady rate including business processing and analytics tools that are being developed or already have been made available for organizations (Bhimani, Mention, \& Barlatier, 2018). Therefore, research completed to support customer relations managers as they navigate these realities can help support the scholar and practitioner states within this phenomenon of study (Gautam \& Sharma, 2017).

Agnihotri et al. (2017) asserted that social media provides feedback for customer relations managers in ways that can support responsiveness and helps anchor the behavioral facets of managers in ways which contribute to building communities as well as contribute to greater human impact. In this case, Agnihotri et al. (2017) discussed the notion that social media creates opportunities for greater consumer voice, whether solicited or unsolicited, which, while positive, can create complexities as well (Bhimani et al., 2018). Organizational performance and customer satisfaction are an arena to which social media can feed and support a greater understanding of data and the process of analysis within a big data frame (Peerayuth \& Pakamon, 2017). For example, many organizations leverage big data from multiple conduits such as mobiles, sensors, and the internet, as well as a metric platform. The plethora of data points can serve to reiforce areas outside of customer satisfaction but also enterprise level elements. These could include usage points, optics around company divisions for marketing, branding and communication, as well as support profile effectiveness (Akar and Dalgic, 2018; Peerayuth \& Pakamon, 2017).

Economic entrance for small to medium size firms is positively influenced as social media provides access as well as community development. This increased access can level the field in relation to exposure, market accessibility and consumer communication (Agnihotri et al., 2017; Reed, 2015). A case example included a company within the meat trade industry where the organization implemented a consumer-centric business model with the utilization of Twitter and Facebook. They crafted a strategy around the ways in which social media (i.e. crowdsourcing) and management practices are enacted which supported implementation fluency and helped mitigate a product recall situation (Colliander, Dahlen, \& Moody, 2015).

Yuu, Xiaozhu, Yung and Sukki (2018) analyzed a transportation companies' utilization of social media and ascertained that the ripple of consumer action and positive feedback supported management in deciphering customer needs within a community forum. Utilizing paratextual methods for social media narrative by customer relations managers supported a higher degree of understanding and engagement with their followers within a branding and marketing vein (Yuu et al., 2018). Within this case, it was clear that the technological tools available were still evolving; however, the infrastructural implications far surpass the problems (Webb \& Roberts, 2016).

Del Rowe (2018) analysed the implications of social media from Fiji Water, a company which carved out its competitive advantage among beverage giants such as Dasani and Aquafina with higher end water and highend beverages. Within this case, the authors argued that social media provides more opportunity for digital influencers. In terms of communication flow and impact, these opportunities have been noted as a bourgeoning aspect that influences consumers at a higher rate from the positive and negative (Quinton, 2013). Del Rowe (2018) asserted that the facets of communication, or interchanges within a social media platform, and the evolving nature of interactive engagement can be opportunities for organizations to have a pulse on consumer needs, product, service or support from an understanding focus (Jaber \& Simkin, 2017; Balaiji, Jhan \& Royne, 2015). However, the constraints is that these forums where digital influencers play a significant role leave 
space for negative commentary and could exacerbate crisis-oriented situations as seen in the Unilever scandal (Hunter, Gough, O'Kane, McKeown, Fitzpatrick, Walker, McKinley, Lee \& Kee, 2018; Agnihotri et al., 2017; Reed, 2015; Preimesberger, 2016; Gregoire, Salle \& Tripp, 2015). It is within these facets that customer relations managers need to understand how best to traverse these elements in order to optimize the positive, inform strategy and mitigate the negative (Jaber \& Simkin, 2017).

From another perspective of looking at the value of social media and customer relationship management, Preimesberger (2016) elucidated that within an acquisition and merger assessment, organizations which utilize their social media within a big data frame, meaning they utilize the data as part of the broader matrix, can produce greater gains as this type of feedback approach provides a more comprehensive framework. It is a value-add from a competitiveness arena (Moreno, Morales, Lockett, \& King, 2018; Orenga \& Chalmet, 2016). Moreover, organizations which seek to merge or acquire companies with existing infrastructure assess the degree to which social media has been integrated into the existing fabric of customer relationship management as it relates to agility of strategy and the like (Gironda \& Korgaonkar, 2018).

Aspects such as customer perceptions, perceived benefits and integration of branding communities are important and tend to be integral aspects as they relate to social media and e-commerce regardless of sector (Grewal et al., 2017; Preimesberger, 2016; Singh, 2017). Singh (2017) discussed the implications of analytics and data-based practices within marketing and management practices. Digitization of organizations can support a higher degree of interactivity as well as confirming or disconfirming facets for informing strategy, responsiveness, and having a clearer pulse within the customer community. A lack of infrastructure or understanding of the benefits of social media can result in lagging approaches to engaging branding communities, as well as to understanding consumer concerns and needs (Gironda \& Korgaonkar, 2018).

Kite (2016) examined the spread of social media in addition to the changes that the current medium has undergone in relation to consumer use, personalized advertising and a litany of other options. For example, Twitter as a social media platform once concentrated on sales and product placement which was not necessarily conducive to the wants of their followership (Liu, Burns, \& Hou, 2017; Kite, 2016). As such, consumer voice influenced the designers of Twitter to move more readily to information sharing, personalization and the delineation of knowledge; the clout, power expression and, as Gironda and Korgaonkar (2018) affirmed, critical mass only reaffirms the importance of a new era which the proliferation of social media has ushered in (Colliander, Dahlen, \& Modig, 2015).

Additionally, as in many cases, customer and organizational connectivity were prioritized (Kite, 2016; Lui et al., 2016). Findlay and van Rensburg's (2018) study evaluated how Twitter connectivity supported higher degrees of understanding and engagement from a consumer to firm and firm to consumer reality. Social media amplifies the impact of human connectivity and communication and transcends political and economic boundaries (Webb \& Roberts, 2016). Part of the conclusions drawn from Findlay and van Rensburg's (2018) study reiterated the importance of understanding the customers from a relationship management point of view through facets such as emotional responses versus orchestrated responses as this can aid in mitigating negative posts or communication. Although their study was completed in South Africa where political and geographically, individual and collective voice may be highly charged, organizations that work within this microcosm can still find a higher level of validity within the context of feedback and communication which informs evidence-based practices for customer relations managers (Findlay \& van Rensburg, 2018). Other cases, such as in Asia, reinforced the same sentiment in that customer relations managers that utilize social media within a big data frame can yield greater product advancement and service offerings than more traditional methods (Benitez, Castillo, Llorens, \& Braojos, 2018).

Xiang, Du, Ma, and Fan (2017) analyzed review platforms within the hospitality sector to assess how data analytics and social media approaches work together to provide a more seamless approach to customer relationship management. Within this case, the authors explained that consumers engage in social media as they want to be heard and engaged with, as well as utilize the information and knowledge that others convey (Xiang et al., 2017; Singh, 2017; Kite, 2016). The authors noted that customer relationship management is integral to navigating within an ever-evolving digital era; cocreation approaches provide a value for customers and bridge a once one-way communicative approach which was supplemented by enterprise data matrices (Xiang et al., 2017; Kim et al., 2016; Quinton, 2013).

In an era where consumers can participate and influence online communities, optics around product and service offerings as well as responses to organizational enactment of marketing strategies are increasingly important. Practitioner magazines such as Forbes and CRM Magazine as stated by Smith (2018) and Aquino (2018) 
asserted that clout, influence and, at times, pressure are pieces of social media oriented customer relationship management and these aspects can result in higher levels of social consciousness purveyed by consumers, but they necessitate responsiveness from an organizational perspective (Yen, 2016). Moreover, Grewal et al. (2017) contributed to an academic exploration of the social media technologies that customers utilize as retailing evolves. The implications for organizations along with what other technologies could do for retailing include further customer engagement in relation to IT tools for social media within an analytics frame, customer purchasing intentions, engagement, organizational advancement and product or service iterative feedback loops (Alhidari, Iyer \& Paswan, 2015; Marion, Barczak \& Hultink, 2014).

Within the conceptualization of social media and customer responsiveness, Balajia, Jha and Royne (2015) explained the connectivity between public and private communications within a social media realm and the implications of attribution, consumer perspectives and loyalty. As with much of the contemporary literature within this phenomenon of study, customer loyalty and responsiveness of organizations from a social relationship vein positively correlate (Balajia et al., 2015). Additionally, if a thorough social media strategy was implemented which includes a two-way communication approach as well as overt and intentional organizational practices that are informed by data from multiple sources (i.e. big data frame and social media), customers will be more apt to participate in solicited or non-solicited feedback (Balajia et al., 2015; Simkin \& Dibb, 2013). For example, Erkan and Evans (2016) asserted that many luxury brands such as Tiffany \& Co. utilize a hybridization of co-creation value practices called story giving whereby customer voice was elicited and shared within internal and external communities by customer relationship departments. What was quickly ascertained by the company was that embedding engaging customer voice into the strategy and then building around it acted as a forum that supported marketing efforts as well as served as a mechanism for branding.

Ngai et al. (2015) assessed the different theories, frameworks and constructs that relate to social media. Their theoretical and conceptual analysis of social media supports an enhanced appreciation of the methods (i.e. social, psycho-behavioral etc.) consumers use to engage. This phenomena and evolution of social media from a theoretical and conceptual vein aids in recognizing the dimensions related to the usage of social media and how this can best serve organizations.

As social media continues to take root as a mainstream form of communication for customers, we see other cases that showcase the importance of customer relationship management and value creation on both organizational and consumer ends (Kobia \& Liu, 2017). Moreno, Morales, Lockett and King (2018) evaluated the site of TripAdvisor which concentrates on consumer travel ratings and, within their study, determined that consumers optimize social media to empower and share their voice regarding product and or service offerings. These communities not only provided value for the travel industry in respective countries but also served to hold companies accountable based on specified criteria and averaging results (Garridu-Moreno et al., 2018). A granular data approach coupled with posted narratives can provide a powerful and more contextual frame for a company's potential and existing customer base (Garridu-Morend et al., 2018; Malthouse et al., 2013). Aquino (2015) reaffirmed the positive implications of reciprocal branding and customer relationship management when strategy is developed around social media while leveraging data analytics as well to provide a more complete representation. From a communications perspective, social media can create a continuum for social responsiveness, consciousness and the positive implications of crowdsourcing processes that help movements take root (Liu et al., 2017).

Chen (2017) promulgated that the implications of lagging infrastructure and lack of strategy around social media, such as customer engagement, intention and communicative approaches, are not always utilized within an IT and customer relationship management frame. The realities of millennial consumers as active participants in social media which translates into crowd sourcing capabilities can provide needed data to inform areas such as marketing, branding and communications (Killian and McManus, 2015). Koo, Joun, Han and Chung (2016) contended that the notion of word of mouth (WOM) and communication theories are exacerbated by social media which certainly have constraining facets; however, the benefits of multiple data points and real time narrative or feedback far outweigh the potential limitations. For example, social media could transcend geography and proliferate globalization in its purest sense. Abdullah (2016) reinforced that the evaluation of social media and dialog mining, the study upheld the notion that communication and language provide windows to customer context; ontological tools help frame enterprise data and give faces and voices to consumers (Boschini, 2015). Moreover, web based analytic tools are constantly evolving. The human condition, which is reflected by managers, leaderships and other stakeholders or decision makers, naivety in relation to managing, sustaining relevance and leveraging one's value proposition may be markedly impeded if social media narratives and analytics capacities are not harnessed (Venciute, 2018; Abdullah, 2016; Ngai et al., 2015). 
As social media platforms evolve and developers continue to understand user needs and preferences, voice and interchanges can continue to serve customer relations management practices by acting as channels for customer feedback and opinion classification (Del Rowe, 2018). For example, purposeful communication and shared opinions, as well as elements such as user attribution can provide context within the narratives, encourage sharing communities and provide access at a global scale (Del Rowe, 2018; Boschini, 2015; Aquino, 2015). Del Rowe (2018) analyzed a corporation in Chicago which had embedded a social media strategy within their customer relations practices and, as a result, established that some of the social media tools that connect to the data analytics frame served to enhance the understanding of customer and employee engagement. This small case study explained the possibilities of co-creation approaches, internal data analytics comprehensiveness, and the provision of context within an internal and external customer-oriented community (Del Rowe, 2018). This example illustrated, albeit on a smaller scale, the positive implications of social media usage within a customer relationship and larger data analytics frame (Bhimani, Mention \& Barlatier, 2018; Mainsah, Brandtzæg, Følstad, 2016).

Simkin and Dibb (2013), within these aspects of digitization and the implications for customers, illustrated the aspects of communication and threats of customer empowerment as nascent factors to engagement. Whether through internal or external usage of social media, at times customers see narratives or posts as potential threats in terms of creating realities which are similar to propaganda or compromising meaning so as to carve out a competitive advantage (Zahoor \& Qureshi, 2017). Customer responsiveness could be impacted by the infrastructure or perceived access points from the organizational level; loyalty and freedom to communicate, as well as aspects of transcendence of action are facets to which customer relationship management are important (Boschini, 2015).

Boschini (2015) argued that whether the narratives are positive or negative can still support innovative and creative practice. Millennials assess their role within social media communities and crowd sourcing approaches which result in voice, agency and a realization of impactful engagement (Gironda \& Korgaonkar, 2018; Aquino, 2015; Boschini, 2015). The dance in which customers and organizations are engaged is a part of the richness of the social media narrative, and data analytics can aid both parties in the process of informing practice, product and service iteration and the like (Xiang, Du, Ma, \& Fan, 2017). Within this realm of customer engagement and social media (i.e. crowdsourcing) management, this innovative field illuminates the importance and considerations of infrastructural mechanics and frame. These considerations, which include strategy and governance in addition to the platforms, are integral to seeing the phenomenon of study in play (Bhimani et al., 2018).

Infrastructure: Realities of Customer Relationship Management. Considerations of the infrastructure and framing of data analytics and system-oriented practices are important to the integration of social media data points as well as the harnessing of a detailed approach to strategy implementation (Guha, Harrigan \& Soutar, 2018). In this research context, infrastructure refers to the technology as well as strategy that a firm has crafted in order to govern their customer relationship approach from the upper echelons and throughout the organization (Guha et al., 2018; Jaber \& Simkin, 2017; Webb \& Roberts, 2016). Gartner (2018) postulated that customer relationship management practices are not as advanced in relation to top echelons of leadership making decisions without feedback and engagement from sales teams or management rungs. The lack of systems thinking, or ecosystem design, as technology multiplies could render organizations hamstrung by archaic practices (Kim et al., 2016; Liyakas, 2013). Liyakasa (2013), in accordance with the Gartner Customer 360 Summit, estimated that organizations spent $\$ 242$ billion in IT expenditures in order to accommodate for big data. The integration of IT systems from an enterprise level as well as within a social media or crowd sourcing approach can support more robust, responsive and intentional applications of data in relation to strategy implementation (Barry \& Gironda, 2018; Moorthy et al., 2015). As the construct of communication has evolved at an unprecedented rate, the usefulness of customer voice in accordance with choice as it relates to crowdsourced data points can support managers in understanding how best to navigate client relationships (Goldenberg, 2017). Customer relations management required a greater understanding of data and analytic processes as well as a newness consternation; not fearing the advancements of data analytics and being able to traverse the influx of information are integral competencies within this position (Goldenberg, 2017). Ensuring that human resource practices as well as training are artfully designed to engage managers that have a level of knowledge and skill within the data world is integral. Providing, 'just in time' supports to advance may be barriers resourcing-wise but should be part and parcel to leadership practices and departmental offerings as they pertain to business intelligence (Strategic Direction, 2017).

Customer autonomy, voice, and ability to influence product or service iteration or practices are a reality with the advancement of social media platforms or entities and should be a significant consideration within an 
organization's data pull and subsequent analytics (Zahoor \& Qureshi, 2018; Singh, 2017). Language, word usage, questioning, and branding communities created and facilitated by customers are realities in many sectors whether retail, commerce, or petroleum (Vickers, 2017). In a two- or multi-pronged communication framework, the ability for customers to impact change, help organizations streamline processes or bolster productivity are immense and should be a part of management considerations (Colliander, Dahlen, \& Modig, 2015). Moreover, as Tse, Loh, Ding and Zhang (2018) reaffirmed in their analysis of a customer recall situation during 2017, the utilization of social media and analytics to ascertain the reach of their message and mitigation points served the company quite well as customers communicated their concerns. Additionally, the company was able to validate the realities of the recall and mitigate the impact of misinformation or alternative facts within a real-time forum (Tse et al., 2018). The training and awareness of managers within a customer relationship realm was integral to the positive gains by the company in optimizing social media in the recall case (Tse et al., 2018; Mariana \& Mohammed, 2014).This co-creation value framework provided ample opportunities for communication such as messaging, question and answers within the emergent customer community, and a higher degree of responsiveness which had tremendous positive gains even within a product recall circumstances (Escobar-Rodriguez, Gravalos-Gastumnza \& Calanos, 2017; Kobia \& Liu, 2017).

Singh (2017) critically analyzed IT investment and infrastructure progression and asserted that it was important for firms to understand that the initial investment in technology could enlighten customer experience and solicit responses from customers can provide greater context in addition to support a holistic communication approach. The data that is collected and subsequently aggregated as The Garter Group (2016) (as cited by Singh, 2017) as essential to enacting an effective strategy. The sample within the study indicated that 70 percent of those surveyed indicated that, as a result of the propagation of social media and crowd sourcing apparatus, a two-pronged strategy for traditional communication and marketing facets as well as digital processes are being developed (Santomier, Hogan, \& Kunz, 2016; Grossberg, 2018). Singh (2017) discussed the implications of critical factors in strategy development which included a two or three dimensional strategy that can include traditional marketing and management approaches in accordance with emergent contemporary strategizing to include data facets from the web, social media and other customer relations management tools.

Chin, Ting, Chi, Han and Chien (2015) addressed an Asian populace called the Otaku group that are known to be affluent as well as vocal customers; the study affirmed that a co-creation value approach provided organizational insight in buying behaviors and needed demographic data that was leveraged by luxury marketoriented companies. Additionally, through data analytics, customer intentions and a greater sense of purchasing behaviors were clearer, and this data was more readily disseminated to the necessary departments.

The claims were reiterated within a practitioner journal which affirmed the benefits of wrapping data analytics within a social media frame, as it helped understand the customers DNA which included:

$>$ Predictive processes.

$>$ Language mining; a fulsome approach to information cleaning; and meaning making.

$>$ Aided in road mapping customer orientation, intentionality and purchasing proclivities (Smilansky, 2015; Fanning \& Grant, 2013; Malthouse et al., 2013).

Since Gartner (2015) forecasted the need for companies to make IT infrastructure augmentations to accommodate for social media, titans like IBM have been engaging in this realm. Many companies have made the infrastructural shift to accommodate for social media amongst their big data or data analytics approach (Zahoor \& Qureshi, 2018; Orenga \& Chalmet, 2016; Smilansky, 2015). A reinforcement that social media provides a series of tangible data points, as Kunz et al. (2017) indicated, offers more contextual facets to traditional data analytics, as voice, feedback and narratives can be used to check other mechanisms of data such as frequency of purchasing and other customer buying behaviors, as well as loyalty predilections (Grewal, Roggeveen, \& Nordfalt, 2017; King, 2016; Fanning \& Grant, 2013).

Goldenberg (2017) underpinned the Gartner Groups assertions in a study which analyzed the IT frame for engaging in social media or crowd sourcing methods. Within this study, the discussion of the rate of data, which is a constraint in the literature for customer relations managers within the knowledge sharing, transfer, and mobilization realities, highlights that organizations should consider four areas infrastructurally. These included:

$>$ Integrating offline and online customer data (i.e. enterprise and social media data).

$>$ Attaining organization buy-in.

$>$ Knowing how to apply big data.

$>$ Creating a meaningful road map. 
Technological infrastructure was one important element of customer relationship management within a more complex people and process management matrix (Goldenberg, 2017; Lager, 2013). These elements affirmed the importance of a concerted customer relationship management framework which at the heart addresses infrastructure design, as well as the human condition in relation to change leadership. Within a contemporary Harvard Business Review article surrounding the state of global market places and the advancement of social media, the discussion of the implications of the volatility of markets and the uncertain nature of consumer practices reaffirmed that social media can aid in navigating the uncertainty (Bennett \& Lemoine, 2014). Additionally, the shifts in resourcing reaffirms the importance of understanding the DNA, or pulse, of customers within the data pull and analysis (Bennett \& Lemoine, 2014).

This digital era is markedly reflective of higher rates of information from the customers directly as a result of increased connectivity. Customer relationship management solutions which included infrastructure or tools which support text mining (Liau \& Tan, 2014; Quinton, 2013). These tools reinforced the idea that content and context are key, underpin the importance of engaging in co-creation value practices as well as robust infrastructure shifts (Romanczuk, Willy \& Bischoff, 2017; Bugshan, 2015). A hybrid of enterprise and crowdsourcing data attainment and analysis are integral to this new reality; the infrastructure progression and initial investment by firms will yield immense benefits within an everchanging economic landscape (Bhimani et al., 2018; Singh, 2017; Lager, 2013).

Communication and Customer-Centricity: The Implications of Co-Creation Value Approaches and Customer Relations. Akar and Dalgic (2018) asserted that consumer purchase intentions, buying behaviors and clout contribute to the rich tapestry of networking and dynamic online community interchanges, as well as to product, service and process iteration. The power of likes, shares and narratives, as Rodriguez, Gastumnza and Calaras (2017) argued, can aid organizations in understanding customer intentions and purchasing behaviors, as does the sampling that is provided in branding communities within social media platforms such as Instagram, Facebook, and LinkedIn (Ascarza, Ebbes, Netzer, Oded, \& Danielson, 2017; Pemberton, 2016; Mariana \& Mohammed, 2014). Customers are integral to the value and effectiveness of organizations within a sales, product development and service realm; data analytics coupled with aspects such as crowd sourcing in branding communities are rich areas for exploration; this dynamism of co-creation reflects the strength of the intersections of communication, social media, data draws, etc. (Papa, Santoro, Tirabeni, \& Monge, 2018; Ismail \& Evans, 2016; Trefler, 2014).

Ismail and Evans (2016) asserted that co-creation value practices built within appropriate mechanisms organizationally can yield increased engagement internally and externally. Feedback, in a feedforward way, elucidates the opportunities within this sphere of technological proliferation. Branding community forums within a social media frame is a fruitful arena for strategies which leverage the co-creative facets that are inherent in the structure and customer relationship management approaches (Papa et al., 2018; Barry \& Gironda, 2018). Homophily, or like-mindedness, can be the anchors of co-creative benefits as constructs such as gregarity, dynamic communication and the realities of crowdsourcing within social media underpin the sheer power of customer relationship management (Gunarathne, Rui, \& Seidmann, 2018; Zhang \& Yet, 2018; King, 2016; Smilansky, 2015; Fanning \& Grant, 2013).

Barriers to Social Media Implementation. The literature indicated that the proliferation of social media within a big data frame has some constraints from a customer relationship management perspective (West, 2017). For example, the impact of negative feedback in a crowdsourcing arena can have tremendous ripple effects if not mitigated by communication mechanisms from a relationship management perspective (Yuu et al., 2018; Zhang \& Yu, 2018; West, 2017). Mob mentality, self-interest, greed and implications of social ecological impact from an anthropological perspective create fear and reticence for customer relations managers because their responsiveness feels high stakes (Hunter et al., 2018). However, as Gunarathne, Rui and Serdmann (2018) and Hunter et al. (2018) asserted, social media provides a "realistic platform for complaints" (p.13) since it provides a medium that is responsive and has tremendous utility (West, 2017). Additionally, the just-in-time capacity or positive effects of product and service iterations, as well as feedback, far surpass the potential constraints (Gunarathne, Rui, \& Serdmann, 2018; Hunter et al., 2018). In two cases dealing with recalls of products in the food industry, the responsiveness of customer relations managers helped weather the potential business viability and market value as consumers were able to voice their concerns in addition to engaging in a community which supported the socially conscious and integrity laden approach (Hunter et al., 2018; Agnihotri et al., 2017; Reed 2015).

West (2017) discussed the reactionary premise of how responding to negative narrative can be managed through the critical awareness of managers and by utilizing the skills to interpret and engage in data analytics. 
The realities of any communicative format can result in positive, negative and mute perspectives or points of consideration. Abedin (2016) asserted that within many platforms which include Facebook, the adoption of the technology with the inclusion of social media and crowdsourcing mechanisms and the realities of negative commentary can be received as unaligned with the intent of the strategy at play. In this vein, whether traditional customer relations management or adaptive analytics, any negative narrative or challenge based on customer voice needs to be considered in the context of governance and the agreed upon approach of organizations (Grewal et al., 2017; Nickerson, Wuebker, \& Zenger, 2017; Orenga \& Chalmet, 2016).

Even though the rate of advancement of social media can be intimidating for most practitioners, the critical pieces are understanding the what's, why's and how's of the medium and the right questions to ask and messaging; within the realm of data, communication from customers is one of the elements that has been amplified, yet an organization's strategic goals, implementation and methods in form have stayed relatively the same (Guha, Harrigan \& Soutar, 2018; Digital Global Report, 2019; Liu et al., 2017). Social media is not going away, and the growth of platforms and usage is exponential (Bhimani et al., 2018). Gartner (2016) argued that by 2020 , over 3.5 billion people will be using social media as a result of universal access to the world wide web through cellphones and other personal devices (Digital Global Report, 2019). In this research, utilized a theoretical backdrop of communication, uses and gratification theories provided the necessary underpinnings for understanding the motivations, actions and subsequent constraints of customer narrative feedback (Kim et al., 2016).

Chen and Popovich's (2003) uses and gratification theory addressed the reasons why consumers utilize social media as means to communicate their purchasing intentions and the like. Chen and Popovich's (2003) work was adapted from Dholakia, Bagozzi and Pearo (2004), who had originally used the theory to examine the social influence of consumers that utilized social media. This theoretical frame includes social media as a technological and communication platform as well as the implications of its use for and on consumers as the technology has become more ubiquitous. Chen and Popovich's (2003) theory offered the opportunity to explore the elements that motivate consumers to use social media which includes behavior, user comfortability and subsequent utility as it relates to consumer satisfaction. These elements could help emphasize the importance of social media narratives in terms of legitimacy of feedback and platform usage and how they can provide a more holistic picture of consumer buying intentions when integrated with big data CRM practices.

Bringing these worlds together, that is, utilizing an overlapping approach of a co-creation value framework of big data and social media narratives could provide a more holistic and comprehensive picture of consumer purchasing intentions (Abdullah, 2016; Kunz et al., 2017). This approach cannot only provide the needed context which some traditional customer relationship management analytics may lack, but also support a more targeted approach to weed through the litany of negative comments. Additionally, having a more holistic picture can support managers in gaining the confidence needed to build the necessary repertoire of questions, understandings and elements linked to digitization, as currently these elements could be considered constraints or barriers. Liu, Burns, and Hou (2017) asserted that these elements are more indicative of web-oriented consumer feedback; synthesizing social media narratives that reflect consumer viewpoints provides a shared value framework and context and form action for managers and subsequently organizations (Abdullah, 2016; Kunz et al., 2017). Abdullah (2016) evaluated the current research around social media and customer relationship management and provided a theoretical discussion of the construct of customer engagement, the usage of social media and how this relates to brand equity. This theoretical facet provided a potential justification for social media narratives within the current CRM information practices. Additionally, the uses and gratification theory could help managers anticipate consumer motivations, behaviors and intentions within the conceptualization of why customers utilize social media platforms. For example, Chen and Popovich (2003) discussed the implications of personal identity, relational facets and the implications of surveillance for customers when choosing what social media platforms, they utilized. Coalescing these elements with communication theory is the dynamism inherent in communication. Whether face to face or on the web, customers could engage within branding communities based on facets such as being heard, a sense of contribution and relationships developed under a sense of purpose within the branding arenas (Kodish, 2015; Berlo, 1960). The extant theoretical basis of communication provides justification for inputting perceived barriers of traditional customer relations manager approaches to attaining information from solely static data points and demographic information into the contextual frames that align with Berlo's (1960) discussion of the "dynamic, ongoing, ever-changing, continuous interchanges" (p. 24) which social media seemingly amplifies. The potential barrier or constraint is an opportunity which scholars within this proliferating field asserted is beneficial to the competitive advantage, efficiencies and effectiveness whether as a product, service or hybrid offering (Guha, Harrigan \& Soutar, 2018; Liu et al., 2017; Lu et al., 2017; Moorthy et al., 2015; Marcus \& Davis, 2014). To reiterate, barriers in traditional customer relations management such as lacking 
strategy, data cleaning, accountability and guidance are still realities with the digitalization approach. Addressing infrastructure which includes strategy, IT systems orientation within a social media or crowdsourcing helps firms in this new era of Web 2.0 technologies to reinvent themselves and lay the foundations for sustainable change (Bhimani et al., 2018; Orenga \& Chalmet, 2016; Dominici, 2015).

Conceptual Framework. The conceptual framework for this multiple case study was foundational to the communication theory and other theoretical and conceptual elements (Kodish, 2013). Within this construct, Parsons and Lepkowski-White (2018) conceptualized social media marketing and management in a way that helped distill how managers navigated within the realm of customer relations management. Communication is evolving within the digital landscape, which leads to the explorative nature of the study. This conceptual framework helped build out the multiple dimensions of communication theory, uses and gratification theory, constructs of feedback, data collection, analysis and the like (Kobia \& Liu, 2017; Khan, 2017; Webb \& Middle, 2016). The conceptual framework underscored four dimensions of consideration which included the elements that informed a firm's strategic focus, for example, messaging/projecting, monitoring, assessing and responding (Parsons \& Lepkowski-White, 2018). Through this lens, I explored how customer relations managers utilize social media within their data practices and how this appears from a consumer perspective. Social media as a technological and communication platform, and the implications of its use for and on consumers as the technology has become more ubiquitous, tied readily in with communication theory and uses and gratification theory (Khan, 2017; Webb \& Middle, 2016).

The conceptualization provided a multi-pronged lens by which to look at an organization's engagement with social media (i.e. crowdsourcing) through a data analytics frame. Parsons and Lepkowski-White's (2018) framework bridged the higher level of strategy and organizational raison d'etre to the application or tactical aspects for customer relations managers. The four core dimensions of messaging/projecting, monitoring, assessing and responding are areas in which customer relations managers as well as other leaders need to readily understand (Parsons \& Lepkowski-White, 2018). The dimensions within the conceptualization highlighted the messaging and projecting which related to how firms engage in social media whether from an information push out or integration of communication and engagement with customers (Parsons \& LepkowskiWhite, 2018). Parsons and Lepkowski-White (2018) did not advocate for one or the other as it is the organization's responsibility to consider what best fits their vision, mission, and governance framework.

These aspects should direct an organizations strategy to engage in the same data analytics surrounding customer behaviors and actions without social media (Parsons \& Lepkowski-White, 2018). For example, if customers tended to communicate via email, the data shows that customers wanted more information on a firm's social actions, an organization's strategy may be directed more at posting information and static approaches to communication. The opposite would hold true as well; understanding the customer relationship management capacity from within as well as the predilections of customers would inform the process of the first dimension as well as the second dimension of monitoring (Parsons \& Lepkowski-White, 2018). The complexities within this area are how experienced or trained customer relations managers are in understanding the data, analysis and implications; how data and messaging fits into the strategies and abilities of managers and departments was integral to how the aspects of monitoring can contribute to the overall effectiveness and efficiencies within the departments and organization as a whole (Parsons \& Lepkowski-White, 2018).

Customer relations managers and their respective departments, as highlighted previously, should have an infrastructure that could help enact strategy which may include tools such as text or word recognition applications that could work within social media mediums and help support efficiencies in the data analytics processes (Kabir, Karim, Newaz, \& Hossain, 2018; Liau \& Tan, 2014).Within a co-value or creation framework, customers could help with the process of analysis in that their feedback can inadvertently act as triangulation mechanisms by confirming, questioning, sharing frustrations, and making recommendations which can be used as part of the understanding and assessment connected to customer relations managers portfolios or core responsibilities (Parsons \& Lepkowski-White, 2018).

Within the conceptualization, Parsons and Lepkowski-White (2018) asserted that organizations can function within these dimensions in a non-sequential manner depending on their mandates, infrastructure and management acuity. Other organizations within the cases explored similar conceptual arenas, in that companies such as Lego, Proctor \& Gamble, Ford and Starbucks created their own strategy and frame for social media approaches that included variances from monitoring, engaging or a hybrid of these conceptions (Kodish, 2015). For example, within an extensive social media literature review, Bhimani et al. (2018) noted that 'My Starbucks Idea' provided the environment for customers to be engaged in ideas or feedback inclusion; Nokia engaged in front-end design by soliciting customer feedback through their branding community. This resulted 
in a very successful WP7 iteration of their mobile phone line. In many of these case examples the predictive analytics of time of day for responses, areas of response and communication style made it easier for the customer service management in shaping their day-to-day responsibilities and dissection of high levels of data and relevance to the organization (Webb \& Roberts, 2016; Kodish, 2015).

The last dimension Parsons and Lepkowski-White (2018) addressed was the facets of responding to the data and information in a way that added value to the organization and customers. Communication methods need to be solidified both at the high level and granularly as the implications of intention, tone, vocabulary, and being able to swing negative narratives or redirect messaging could be a delicate balance. However, in the recall cases discussed earlier, King (2015) asserted that the relationships cultivated as a result of applying a framework which reflected integrity, genuine concern, social consciousness and ethical practice helped guide the responding applications that were utilized (Parsons and Lepkowski-White, 2018). A particularly poignant consideration was, as organizations evolved their infrastructure, the organizational language, graphics and incentivization approaches should managers implement as the online community may not have been as receptive to more traditional face-to-face methods (Parsons \& Lepkowski-White, 2018).

In conclusion, this conceptual framework integrated the theoretical elements such as the evolution of communication and the pragmatic aspects of integrating social media practices within a data analytics frame (Webb \& Roberts, 2016; Moorthy et al., 2015).

The richness of this conceptualization is embedded in (Parsons \& Lepkowski-White, 2018), and it:

1. Assumed that social media and data analytical practice would reflect strategy and are part of a 'now' reality for organizations.

2. Synthesized the realities that were faced by customer relations managers and attempted, through the dimensions in the framework, to mitigate perceived constraints in a value-add approach.

3. Highlighted the core elements of a co-creation approach whereby customers are a large part of the conversation whether in data pulls (crowdsourcing) or online community engagement.

4. Served to inadvertently hold organizations from the leadership to customer relations managers accountable for the positive engagement of customers within a social media context. (i.e. shared accountability) 5. Provided latitude for customer relations managers and organizations to consider the dimensions within social media and data analytics yet are not beholden to a one size fits all mentality.

Within the research, the conceptualization provided the necessary foundation for exploring the phenomenon of how customer relations managers could utilize social media within big data/data analytics frame to support targeted and agile marketing and management strategies (Grewal et al., 2017). Additionally, with the consideration of communication and technological usage, the design was pre-emptive in accordance with the constraints that customer relations managers saw contemporarily which this study attempts to further explore. Throughout the literature review, cases of organizations that have been successful in this realm as well as the subsequent gains have been highlighted. The theoretical facets such as communication theory, uses and gratification theory as well as the pragmatic aspects are integrated into the realities for customer relations managers. These included a broad spectrum of considerations interwoven throughout the discussion of social media and marketing strategies.

\section{Gap in the Literature}

The literature review served to anchor the gap established in this study which was the missing explorations of contextual necessities, realities of social media and customer relations management. An exploration of constraints within how social media was navigated informed customer relations and the yielded gains within existing cases served to provide further reasoning for exploring customer relations managers understandings and what customers could provide within a Canadian context. The gap in strategy and IT infrastructural implementation and understanding, and ability to manage within these platforms is evolving at a steady rate due to the proliferation of technology, business processing and analytics tools that are being developed or already have been made available for organizations (Bhimani, Mention, Barlatier, 2017).

The gap in the research in terms of a deeper understandings for customer relations managers, of the benefits of leveraging social media (i.e. infrastructure and strategy) to help inform the existing data frame and analytics was clear and reinforced the validity of this study. Additionally, the study's data collection with customer relations managers, business analysts that were engaged in customer relations management to ascertain their perspectives surrounding cocreation or a shared value frame. In addition, the challenges managers face served as 
rich consideration which align readily with the literature and intentions in the phenomenon of study (Haenlein \& Libai, 2017; Erkan \& Evans, 2016).

\section{Summary and Conclusion}

This study was intended to explore what the common understandings of customer relations managers were that utilize social media within a data analytics (i.e. big data) frame to support targeted and agile marketing and management strategies (Parsons \& Lepkowski-White, 2018; Zahoor \& Qureshi, 2017; Kunz et al., 2016). As a result, this literature review has interwoven the state of big data analytics and crowdsourcing through social media in relation to the benefits and challenges (Bhimani et al., 2018; Kabir, Karim, Newaz, \& Hossain, 2018; Steiger, Matzler, 2012). This reaffirmed the current state of many organizations in luxury markets in Asia, online service or rating conglomerates that are in their infancy in social media realms and utilize at least one method of crowdsourcing whether from online community narratives, responsive two-way feedback mechanisms, frequency data analytics from platforms such as Facebook, Twitter or Instagram and the like (Liu, Burns, \& Hou, 2017; Escobar-Rodriguez, Grávalos-Gastaminza, \& Pérez-Calañas, 2017; Colliander, Dahlen, \& Modig, 2015).

The multi-pronged benefits of crowdsourcing in social media included understanding the pulse and DNA of the customers and provided increased voice and purpose for customers in relation to product and service offerings; real-time feedback for organizations to support increased efficiencies and productivity (Smilansky, 2015; Fanning \& Grant, 2013; Malthouse et al., 2013). The information and data garnered from crowdsourcing in the form of social media also served to support a natural qualifier or deduction method related to other data analytical processes within enterprise capacity.

Overall, the organizations that could conceptualize the promise and potential of data analytics akin to social media and have invested in developing a strategy around social media, infrastructure alignment and the implications of communication may be more innovative in their practice (Bhimani et al., 2018; Parsons \& Lepkowski-White, 2018; Patroni, von Briel \& Recher, 2016; Ngai et al., 2015). Moreover, the literature showcased that the contextual facets that are not overt in traditional data analytics could be brought to life more readily when leveraging social media narratives (i.e. crowdsourcing) as a means to give greater voice, targeted inputs and a forum for intentional feedback (Halale, Gangadharan \& Uden, 2015; Schlagwein \& Bjorn-Andersen, 2014). These benefits coupled with an understanding and picture of customer buying behaviors and intentions and the application tools such as key word identifiers can provide rich contextual and more nuanced facets for customer relations managers and their departments to support more accurate and agile practices (Bhimani et al., 2018; Parsons \& Lepkowski-White, 2018; Patroni, von Briel \& Recher, 2016).

In the literature reviewed, the volume of cases of organizations that are integrating social media (i.e. crowdsourcing) methods through platforms such as Twitter, Facebook, and Instagram or other regional platforms that were similar in service offering reflected the immensity of buy-in, regardless of the potential constraints which included, pace of information, amount of data, impact of input within online communities (Goldenberg 2017; West, 2017). Globally, there are more than 3.4 billion consumers that engage in social media which provides a larger reach, higher potential productivity, performance and ultimately, sales for those organizations (Global Digital Report, 2019). These customers are primarily millennials, but a large segment transcend this generation due to the proliferation of the cell phone and web applications that provide greater opportunities for those that have access. These customers also engaged in the service and product offerings and online communities for support, collegial interchanges and sharing of buying intentions, agency, efficacy, and other tenets of consumer identity (Del Rowe, 2018; Ye, Hashim, Baghirov \& Murphy, 2018).

Customer relations managers could harness this information, interchange and voice of their followers as well as the criticality that also happens within these forums. Critique, or what may seem like negative narratives to customer relations managers that have digital competencies, understand the opportunities within the words can be a very powerful tool for product and service innovation (Bhimani et al., 2018; Goldenberg, 2017). Additionally, the alignment of leadership in terms of governance and strategy delineation as it relates to competency and comfortability of customer relations managers is certainly a key success factor as Parsons and Lepkowski-White (2018) and Banyai (2016) asserted. Aiding managers in understanding this digital reality and navigating their space to be confident in the information and knowing the right questions to ask and approaches to enact strategy can provide the needed elements to cultivate a dynamic systems level approach as it relates to strategy enactment, marketing, and management (Courchesne, Ravanas \& Pulido, 2019; Abdullah, 2016; Banyai, 2016). 
Organizations could implement a strategy which support direct engagement or monitoring/observation and synthesis of social media narrative data with perhaps the fear of high stakes communication for managers as the technology proliferated (Parsons \& Lepkowski-White, 2018). Understanding where customer relations management practices were within a Canadian context was beneficial. The opportunity for a co-creation value model, whether through overt responsiveness or monitoring oriented responsiveness, provided a space for customers to contribute more readily to the approaches of a once one-dimensional customer relations framework (Bhimani et al., 2018). The realities for customer relations managers and how social media could support organizations within this phenomenon of study could enlighten researchers and practitioners and acted as a bridge for aspects that could influence further innovation in this field. This will be the primary focus in the research method discussion.

\section{Study Significance}

Significance to Practice. Based on the research, many companies have not harnessed the true power of social media for many reasons which, in the context of data analytics, can impinge on the more fulsome picture of consumer purchasing intentions (Abdullah, 2016). Customer relations management in this digital era encompasses a plethora of communication points such as marketing and feedback from a customer perspective, purchasing context, intention, motivation, and buying patterns/behaviors. Other less intangible reasons such as ethical commitments or community programs that are fostered by firms, if leveraged more readily, could be more authentic, comprehensive and more aptly inform strategy (Parsons \& Lepkowski-White, 2018). Based on the dynamism of social media, the voice of consumers is not leveraged as readily and could help companies attain a deeper understanding of purchase intentions which can inform more holistic customer relations management (Kunz et al., 2017). This research could support managers attempting to navigate this evolving landscape and further engage them in more targeted and agile customer relations management approaches.

Significance to Theory. As social media proliferates, companies are faced with realities such as the need for infrastructure changes, strategy augmentation, and communication approaches that are more dynamic (Papagiannidis \& Bourlakis, 2015). The results of this study could add to the communications theory and customer relationship conceptualization that linked processes at a management and customer level and could facilitate social change (Killian \& McManus, 2015). Uses and gratification theory, while, it was not substantial in this research, could be an area of continued development (Chen \& Popovich, 2003). Researchers that want to mobilize the knowledge and adaptability of customer relations management in this state of technological proliferation might value the contributions of this literature.

Significance to Social Change. The relationship of social change included that customer relations managers could utilize the interview feedback from customers in order to understand how an organization's product and service offerings were being applied and how they could improve (Orenga \& Chalmet, 2016). In an era where the proliferation of technology and the use of social media is evolving, how the growing socially conscious consumers choice was based on ethics as well as utility. The social and political impact could provide an outlet or unpin a level of positive influence on organizations whether applied to service, product or multi-oriented providers (Abdullah, 2016; Grewal, Roggeveen, and Nordfalt, 2017).

Customer relations managers could gain needed insight as to how best support or apply aspects of the triple bottom line in their own organizational mandate (Connelly, 2012; Abdullah, 2016). Furthermore, this study could help identify an understanding of the increasing socially conscious consumer behaviors such as choosing fair trade products or backing companies that engage in social enterprise (Dominici, 2015). This is readily becoming part of the norm which not all industries have tapped into; the narrative or voice which social media provides is now readily accessible and should be part of the CRM considerations (Dominici, 2015).

\section{References}

1. Aquino, J. (2015). The pros and cons of crowdsourcing. CRM Magazine, 17(2), 30-34. Retrieved from: Walden Databases.

2. Abdullah, S. S. (2016). Brand equity through customer engagement in social media: A critical review. Journal of Business and Management, 18(8), 38-46. DOI:10.9790/487X.

3. Abedin, B. (2016) Diffusion of adoption of Facebook for customer relationship management in Australian exploratory study. Journal of Organizational and End User Computing (JOEUC), 28(1), 56-72. DOI:10.4018/JOEUC.2016010104.

4. Adams, S. A., (2014). Maintaining the collision of accounts: crowd sourcing sites in health care as brokers in the co-production of pharmaceutical knowledge. Information Communication Society, 17(6), 657-669. DOI: $10.1080 / 1369118 X .2013 .808362$. 
5. Agnihotri, R., Trainor, K. J., Itani, O. S., \& Rodriguez, M. (2017). Examining the role of sales-based CRM technology and social media use on post-sale service behaviors in India. Journal of Business Research, 81(C), 144-154. doi: 10.1016/jbusres. 2017.08.021.

6. Akar, E., \& Dalgic, T. (2018). Understanding online consumers' purchase intentions: a contribution from social network theory. Behaviour \& Information Technology, 37(5), 473-487. doi:10.1080/0144929X.2018.1456563.

7. Alasuutari, P. (2010). The rise and relevance of qualitative research. International Journal of Social Research Methodology, 13, 139-155. doi:10.1080/13645570902966056.

8. Alhidari, A., Iyer, P., \& Paswan, A. (2015). Personal level antecedents of eWOM and purchase intention, on social networking sites. Journal of Customer Behaviour, 14(2), 107-125. DOI:10.1362/147539215X14373846805707.

9. Ascarza, E., Ebbes, P., Netzer, Oded, \& Danielson, M. (2017). Beyond the Target Customer: Social Effects of CRM Campaigns, Journal of Marketing Research, 54(3), 347-363. https://doi.org/10.1509/jmr.15.0442.

10.Balaji, M. S., Jha, S., \& Royne, M.B. (2015). Customer e-complaining behaviours using social media. The Services Industries Journal, 633-654. Doi: 10.1080/02642069.2015.1062883.

11.Bansal, P., \& Corley, K. (2011). The coming of age for qualitative research: Embracing the diversity of qualitative research. Academy of Management Journal, 54(2), 233-237. https://doi.org/10.5465/amj.2011.60262792.

12.Banyai, E. (2016). The integration of social media into corporate processes. Society \& Economy, 38(2), 239-259. doi:10.1556/204.2016.38.2.6.

13. Barratt, M., Thomas Y. Choi, \& Mei Li. (2011). Qualitative case studies in operations management: Trends, research outcomes, and future research implications. Journal of Operations Management, 29, 329-342. doi:10.1016/j.jom.2010.06.002.

14.Barry, J. M., \& Gironda, J. (2018). A dyadic examination of inspirational factors driving B2B social media influence. Journal of Marketing Theory \& Practice, 26(1/2), 117-143. doi:10.1080/10696679.2017.1389244.

15.Bashir, N., Papamichail, K. N., \& Malik, K. (2017). Use of social media applications for supporting new product development processes in multinational corporations. Technological Forecasting and Social Change, 120, 176-183. https://doi.org/10.1016/j.techfore.2017.02.028.

16. Benitez, J., Castillo, A., Llorens, J., Braojos, J., 2018. IT-enabled knowledge ambidexterity and innovation performance in small US firms: the moderator role of social media capability. Information Management, 55(1), 131-143. https://doi.org/10.1016/j.im.2017.09.004.

17.Bennett, B., \& Lemoine, J. (2014). What VUCA Really Means for You. Harvard Business Review, January 2014 Issue. Retrieved from https://hbr.org/2014/01/what-vuca-really-means-for-you.

18.Berlo, D. (1960). The process of communication, New York: Holt, Reinhart, and Winston.

19.Bhimani, H., Mention, A. L., \& Barlatier, P.J. (2018). Social media and innovation: A systemic literature review and future research directions. An International Journal of Technological Forecasting and Social Change, 5(3), 1-19. Doi: 10.1016/j.techfore.218.10.007.

20.Bleijenbergh, I., Korzilius, H., \& Verschuren, P. (2011). Methodological criteria for the internal validity and utility of practice-oriented research. Quality and Quantity, 45(1), 145-156. doi:10.1007/s11135-0109361-5.

21.Boschini, A. (2015). Starting a conversation through the clutter. Home Accents Today, 66.

22. Bontempi, G. (2016). The Hume problem: A bias/variance argument. Working Paper, ULB Machine Learning Group. Doi: 10.13140RG222998848008.

23.Boston Consulting Group. (2018). The most innovative companies 2018: Innovators go all in on digital. The Boston Consulting Group Retrieved from. http://image-src.bcg.com/Images/BCGMost-InnovativeCompanies-Jan-2018_tcm9-180700.pdf.

24.Brandtzaeg, P. B., Følstad, A., (2016). Social media use and innovations: introduction to the special issue. Journal of Media Innovation, 3(1), 1-3. DOI: 10.5617/jmi.v3i1.2862.

25.Carcary, M. (2009). The research audit trial -- Enhancing trustworthiness in qualitative inquiry. Electronic Journal of Business Research Methods, 7(1), 11-23. DOI: 10.1002/nur.4770160309.

26. Chen, Y. R. (2017). Perceived values of branded mobile media, consumer engagement, business-consumer relationship quality and purchase intention: A study of WeChat in China. Public Relations Review, 43(5), 945954. doi:10.1016/j.pubrev.2017.07.005.

27.Chen, I.J. Popovich, K. (2003). Understanding customer relationship management (CRM): people, process and technology. Business Process Management Journal, 9(5), 672-688. https://doi.org/10.1108/14637150310496758. 
28.Chih-Chin, L., Yu-Ting, W., Yi-Chi, C., Siao-Han, L., \& Yi-Chien, C. (2015). Impulsive Buying Behavior of Otaku Undergraduate Students. Marketing Review / Xing Xiao Ping Lun, 12(2), 139-160. Retrieved from: $\mathrm{https}: / /$ scholar.google.com/scholar?cluster $=12212631898222818728 \& \mathrm{hl}=\mathrm{ru} \& \mathrm{as} \_\mathrm{sdt}=0,5 \&$ sciodt $=0,5$.

29. Cho, J. Y., \& Lee, E. H. (2014). Reducing confusion about grounded theory and qualitative content analysis: Similarities and differences. The Qualitative Report, 19(32), 1-20. Retrieved from: http://nsuworks.nova.edu/tqr/vol19/iss32/2.

30.Connelly, C., Emotional Equations. (2012, November 7). Is social actualization replacing selfactualization? [Blog post]. Retrieved from: http://emotionalequations.com/is-social-actualizationreplacing-self-actualization/.

31.Colliander, J., Dahlen, M., \& Modig, E. (2015). Twitter for two: Investigating the effects of dialogue with customers in social media. International Journal of Advertising: The Review of Marketing Communication, 34(2), 181-194. doi:10.1080/02650487.2014.996197.

32. Courchesne, A., Ravanas, P., \& Pulido, C. (2019). Using Technology to Optimize Customer Relationship Management: The Case of Cirque du Soleil. International Journal of Arts Management, 21(2), 83-93.

Retrieved from: https://search-ebscohostcom.ezp.waldenulibrary.org/login.aspx $?$ direct=true $\& d b=b t h \& A N=135073830 \&$ site=ehost-live \&scope $=$ site

33. Cox, R. (2012). Teaching qualitative research to practitioner-researchers. Theory into Practice, 51(2), 129-139. doi:10.1080/00405841.2012.662868.

34.Creswell, J. W. (2014). Research design: Qualitative, quantitative and mixed methods approaches (4th ed.). Thousand Oaks, CA: Sage Publications, Inc. DOI: 10.5539/elt.v12n5p40.

35.Cypress, B. S. (2017). Rigor or reliability and validity in qualitative research: Perspectives, strategies, reconceptualization, and recommendations. Dimensions of Critical Care Nursing, 36(4), 253-263. doi:10.1097/DCC.0000000000000253.

36. Del Rowe, S. (2018). Tapping into social sphere of influence. CRM Magazine, 22(1), 26-30. Retrieved from: https://www.questia.com/magazine/1G1-525003842/tapping-into-social-s-sphere-of-influence-digital.

37.Dholakia, U. M., Bagozzi, R. P., \& Pearo, L. K. (2004). A social influence model of consumer participation in network- and small- group-based virtual communities. International Journal of Research in Marketing, 21, 241-263. https://doi.org/10.1016/j.ijresmar.2003.12.004.

38.Dominici, G. (2015). Systems thinking and sustainability in organizations. Journal of Organisational Transformation \& Social Change, 12(1), 1-30. doi: 10.1179/1477963314Z.00000000036.

39.Escobar-Rodríguez, T., Grávalos-Gastaminza, M. A., \& Pérez-Calañas, C. (2017). Facebook and the intention of purchasing tourism products: moderating effects of gender, age and marital status. Scandinavian Journal of Hospitality \& Tourism, 17(2), 129-144. doi:10.1080/15022250.2015.1137784.

40.Echambadi, R., Campbell, B., \& Agarwal, R. (2012). Encouraging best practice in quantitative management research: An incomplete list of opportunities. Journal of Management Studies, 23, 801-820. doi:10.1111/j.1467-6486.2006.00660.x.

41.Eshlaghy, T. E., Chitsaz, S., Karimian, L., \& Charkhchi, R. (2011). A classification of qualitative research methods. Research Journal of International Studies, 20, 106-123. Retrieved from: http://www.eurojournals.com/rjis.

42.Erkan, I., \& Evans, C. (2016). The influence of eWOM in social media on consumers' purchase intentions: An extended approach to information adoption, Computers in Human Behavior 61, 47-55. DOI:10.1016/j.chb.2016.03.003.

43.Fanning, K., \& Grant, R. (2013). Big Data: Implications for financial managers. Journal of Corporate Accounting \& Finance, 24(5), 23-30. doi:10.1002/jcaf.21872.

44.Feilzer, M. Y. (2010). Doing mixed methods research pragmatically: Implications for the rediscovery of pragmatism as a research paradigm. Journal of Mixed Methods Research, 4, 6-16. doi:10.1177/1558689809349691.

45.Findlay, K., \& van Rensburg, O. J. (2018). Using interaction networks to map communities on Twitter. International Journal of Market Research, 60(2), 169-189. doi:10.1177/1470785317753025.

46.Smith, A. (2018). How to build lasting customer relationships, Forbes Magazine. Retrieved from: https://www.forbes.com/sites/anthonysmith/2018/08/01/how-to-build-lasting-customerrelationships/\#3d5ebd0d447a.

47.Frels, R. K., \& Onwuegbuzie, A. J. (2013). Administering quantitative instruments with qualitative interviews: A mixed research approach. Journal of Counseling \& Development, 91, 184-194. doi:10.1002/j.1556-6676.2013.00085.x. 
48.Gautam, V., \& Sharma, V. (2017). The mediating role of customer relationship on the social media marketing and purchase intention relationship with special reference to luxury fashion brands. Journal of Promotion Management, 23(6), 872-888. doi:10.1080/10496491.2017.1323262.

49. Gironda, J. T., \& Korgaonkar, P. K. (2018). iSpy? Tailored versus invasive ads and consumers' perceptions of personalized advertising. Electronic Commerce Research \& Applications, 2964-77. doi:10.1016/j.elerap.2018.03.007.

50.Goldenberg, B. (2017). Four big barriers to an integrated customer-centric strategy. Customer Experience Journal. Retrieved from: https://www.ismguide.com/book.

51. Grégoire, Y., Salle, A., \& Tripp, T. M. (2014). Managing social media crises with your customers: The good, the bad, and the ugly. Business Horizons, 58(2), 173-182. https://doi.org/10.1016/j.bushor.2014.11.001.

52.Grewal, D., Roggeveen, A., \& Nordfalt, J. (2017). The future of retailing. Journal of Retailing, 93, 1-6. Doi: 10.1016/j.jretai.2016.12.008.

53. Grossberg, K.A. (2018). The new marketing solutions that will drive strategy implementation. Strategy \& Leadership, 44(3), 20-26. https://doi.org/10.1016/j.bushor.2014.11.001.

54.Guha, S., Harrigan, P., \& Soutar, G. (2018). Linking social media to customer relationship management (CRM): a qualitative study on SMEs. Journal of Small Business \& Entrepreneurship, 30(3), 193-214. https://doi-org.ezp.waldenulibrary.org/10.1080/08276331.2017.1399628.

55. Gunarathne, P., Rui, H., \& Seidmann, A. (2018). When social media delivers customer service: Differential customer treatment in the airline industry. MIS Quarterly, 42(2), 489-520. https://doi.org/10.25300/MISQ/2018/14290.

56. Haenlein, M., \& Libai, B. (2017). Seeding, Referral and Recommendation: Creating Profitable Word-ofMouth Programs, California Management Review, 59(2), 68-91. Retrieved from: http://michaelhaenlein.eu/?page_id=35.

57.Holtzblatt, L., \& Tierney, M.L., (2011). Measuring the effectiveness of social media on an innovation process. In: Proceedings of the 2011 Annual Conference Extended Abstracts on Human Factors in Computing Systems. ACM, New York, 697-712. https://doi.org/10.1145/1979742.1979669.

58. Hunter, R. F., Gough, A., O’Kane, N., McKeown, G., Fitzpatrick, T., Walker, M., McKinley, M, Lee \& Kee, L. (2018). Ethical Issues in Social Media Research for Public Health. American Journal of Public Health, 108(3), 343-348. Retrieved from: https://ajph.aphapublications.org/doi/abs/10.2105/AJPH.2017.304249?af=R\&.

59.Ismail, E. \& Evans, C. (2016). The influence of eWOM in social media on consumers' purchase intentions: An extended approach to information adoption. Computers in Human Behavior, 61, 47-55. Doi: 10.1016/j.chb.2016.03.003.

60. Jaber, F., \& Simkin, L. (2017). Unpicking antecedents of CRM adoption: a two-stage model. Journal of Strategic Marketing, 25(5/6), 475-494. https://doi-org.ezp.waldenulibrary.org/10.1080/0965254X.2016.1149212.

61.Jacob, S. A., \& Ferguson, S. P. (2012). Writing interview protocols and conducting interviews: Tips for students new to the field of qualitative research. The Qualitative Report, 17(42), 1-10. Retrieved from: http://nsuworks.nova.edu/cgi/viewcontent.cgi?article=1718\&context=tqr.

62.Kabir, A. I., Karim, R., Newaz, S., \& Hossain, M.I. (2018). The Power of Social Media Analytics: Text Analytics Based on Sentiment Analysis and Word Clouds. Informatica Economică, 22(1), 25. DOI:10.12948/issn14531305/22.1.2018.03.

63. Kaplan, A., \& Haenlein, M. (2010). Users of the world unite! The challenges and opportunities of social media. Business Horizons, 53, 59-68. DOI: 10.1016/j.bushor.2009.09.003.

64. Killian, G., \& McManus, K. (2015). A marketing communication approach for the digital era: Managerial guidelines for social media integration. Business Horizons, 58(5), 539-549. doi:10.1016/j.bushor.2015.05.006.

65.King, A., \& Lakhani, K. R., (2013). Using open innovation to identify the best ideas. MIT Sloan Management Review, 55(1), 41. Retrieved from: https://www.researchgate.net/publication/257526888_Using_Open_Innovation_to_Identify_the_Best_Ideas.

66. Kim, Y., Kim, Y., Wang, Y., \& Lee, N. Y. (2016). Uses and Gratifications, Journalists' Twitter Use, and Relational Satisfaction with the Public. Journal of Broadcasting \& Electronic Media, 60(3), 503-526. doi:10.1080/08838151.2016.1164171.

67.Kite, L. (2016). Goodbye to Twitter's Buy Button. CRM Magazine, 20(9), 18. Retrieved from: https://www.destinationcrm.com/Articles/ReadArticle.aspx?ArticleID=113272.

68. Kodish, S. (2015). Cultivating Relationships with Customers: The Social Media Challenge. Journal of Leadership, Accountability \& Ethics, 12(2), 81-91. Retrieved from: http://t.www.nabusinesspress.com/JLAE/KodishS_Web12_2_.pdf. 
69.Kobia, C., \& Liu, C. (2017). Why Forward Viral Fashion Messages? The Moderating Roles of Consumers' Fashion Traits and Message Orientation. Journal of Internet Commerce, 16(3), 287-308. doi:10.1080/15332861.2017.1324651.

70.Koo, C., Joun, Y., Han, H., \& Chung, N. (2016). A structural model for destination travel intention as a media exposure. International Journal of Contemporary Hospitality Management, 28(7), 1338-1360. doi:10.1108/IJCHM-07-2014-0354.

71.Kunz, W., Aksoy, L., Bart, Y., Heinonen, K., Kabadayi, S., Villaroel Ordenes, F., Sigala, M., Diaz, D., \& Theodoulidis, B., (2017). Customer Engagement in a Big data World, Journal of Services Marketing, 31(2), 161-171. Retrieved from: https://www.researchgate.net/publication/311767636_Customer_Engagement_in_a_Big_Data_World.

72.Kvale, S. (2007). InterViews - an introduction to qualitative research interviewing, Sage Publications, Thousand Oaks, London. DOI: 10.1108/JSM-10-2016-0352.

73.Lager, M. (2013). New year, New strategies 2014. CRM Magazine, 17(12), 28-32. Retrieved from: https://www.destinationcrm.com/Authors/3117-Marshall-Lager.htm.

74.Liu, X., Burns, A. C., \& Hou, Y. (2017). An investigation of brand-related user-generated content on Twitter. Journal of Advertising, 46(2), 236-247. doi:10.1080/00913367.2017.1297273.

75.Liyakasa, K. (2013). Big data and customer experience begin to converge. CRM Magazine, 17(7), 20. Retrieved from: https://www.destinationcrm.com/Articles/ReadArticle.aspx?ArticleID=90142.

76. Maecker, O., Barrot, C., \& Becker, J. (2016). The effect of social media interactions on customer relationship management. Business Research, 9(1), 133-155. doi:10.1007/s40685-016-0027-6.

77. Mainsah, H., Brandtzæg, P. B., Følstad, A. (2016). Bridging the generational culture gap in youth civic engagement through social media: lessons learnt from young designers in three civic organisations. Journal of Media Innovation. 3(1), 23-40. https://doi.org/10.1016/j.techfore.2018.10.007.

78. Marcus, G., \& Davis, E. (2014). Eight (No, Nine!) problems with big data. Retrieved December 11, 2017, from: https://www.nytimes.com/2014/04/07/opinion/eight-no-nine-problems-with-big -data.html.

79. Mariani, R., \& Mohammed, D. (2014). "Like" a global endorsement: How clicking "Like" Influences Facebook Users Brand Recall and Future Purchasing Intentions. Journal of Management Policy \& Practice, 15(4), 51-63. https://doi.org/10.1016/j.im.2019.103249.

80. Malthouse, E. C., Haenlein, M., Skiera, B., Wege, E., \& Zhang, M. (2013). Managing customer relationships in the social media Era: Introducing the social CRM house. Journal of Interactive Marketing (Mergent, Inc.), 27(4), 270-280. doi:10.1016/j.inymar.2013.09.008.

81. Marion, T. J., Barczak, G., \& Hultink, E.J. (2014). Do social media tools impact the development phase? An exploratory study. Journal of Practice Innovation Management. 31(S1), 18-29. https://doi.org/10.1111/jpim.12189.

82.Moorthy, J., Lahiri, R., Biswas, N., Sanyal, D., Ranjan, J., Nanath, K., \& Ghosh, P. (2015). Big data: Prospects and challenges. Vikalpa: The Journal for Decision Makers, 40(1), 74-96. doi: $10.1177 / 0256090915575450$.

83.Moreno, A., Morales, V., Lockett, N., \& King, S. (2018). The missing link: Creating value with social media use in hotels. International Journal of Hospitality Management, 75(1), 94-104. doi:10.016/j.ijhm.2018.03.008.

84.Ngai, E. W., Tao, S. S., \& Moon, K. K. (2015). Social media research: Theories, constructs, and conceptual frameworks. International Journal of Information Management, 35(1), 33-44. doi:10.1016/j.ijinfomgt.2014.09.004.

85.Nickerson, J. A., Wuebker, R., \& Zenger, T. (2017). Problems, theories, and governing the crowd. Strategic Organization, 15(2), 275-288. https://doi.org/10.1177/1476127016649943.

86.Papagiannidis, S., \& Bourlakis, M., (2015). Special issue theme: social media: a revolution in communication. Technology Forecasting. Social Change Journal, 95(1), 1-2. DOI:10.1016/j.techfore.2014.09.011.

87.Papa, A., Santoro, G., Tirabeni, L., \& Monge, F. (2018). Social media as tool for facilitating knowledge creation and innovation in small and medium enterprises. Baltimore Journal of Management, 13(3), 329-344. https://doi.org/10.1108/BJM-04-2017-0125.

88.Parsons, A., \& Lepkowski-White, E. (2018). Social media marketing management: A conceptual framework. Journal of Internet Commerce, 17(2), 81-95. DOI: 10.1080/15332861.2018.1433910.

89.Patroni, J., von Briel, F., \& Recker, J. (2016). How enterprise social media can facilitate innovation. ITProf. 18(6), 34-41. doi:10.1109/MITP.2016.102.

90.Patton, M. Q. (2014). Qualitative research \& evaluation methods: Integrating theory and practice. Thousand Oaks, CA: SAGE Publications. Retrieved from: 
https://www.betterevaluation.org/en/resources/guide/qualitative_research_and_evaluation_methods_integratin g_theory_and_practice_fourth_edition\%29.

91.Peerayuth C., \& Pakamon S. (2017). Social media use for CRM and business performance satisfaction: The moderating roles of social skills and social media sales intensity. Asia Pacific Management Review, 22(1), 25-34. https://doi-org.ezp.waldenulibrary.org/10.1016/j.apmrv.2016.10.005.

92.Pemberton, A. (2016). Apps are out, bots are in... or so Facebook says. Campaign, 35. Retrieved from: https://mashable.com/2016/04/12/facebook-bots-analysis/.

93.Pentina, I., Guilloux, V., \& Mixer, A. (2018). Exploring Social Media Engagement Behaviors in the Context of Luxury Brands. Journal of Advertising, 47(1), 55-69. DOI: 10.1080/00913367.2017.1405756.

94.Preimesberger, C. (2016). Salesforce reportedly considering acquiring twitter. Eweek, 1. Retrieved from: https://www.eweek.com/cloud/salesforce-reportedly-considering-acquiring-twitter.

95.Quinton, S. (2013). The community brand paradigm: A response to brand management's dilemma in the digital era. Journal of Marketing Management, 29(7/8), 912-932. DOI: 10.1080/0267257X.2012.729072.

96. Orenga, R., \& Chalmet, R. (2016). Social customer relationship management: taking advantage of Web 2.0 and Big data technologies. SpringerPlus, 5(14). doi: 10.1186/s40064-016-3128-y.

97. Rizkallah, J. (2017). The big (unstructured) data problem. Forbes Magazine. Retrieved from: https://www.forbes.com/sites/forbestechcouncil/2017/06/05/the-big-unstructured-dataproblem/\#316e677e493a.

98. Romanczuk, G.E., Willy, C. \& Bischoff, J.E., (2017). Critical success factors for crowdsourcing with virtual environments to unlock innovation. Defense Acquisition Research Journal: A Publication of the Defense Acquisition University, 24(2), 334-367. Retrieved from: https://www.dau.edu/library/arj/p/Defense-AcquisitionResearch-Journal-Current-Issue.

99. Roulston, K. (2013). Interviews in qualitative research. The Encyclopedia of Applied Linguistics. Roulston.

100. Rubin, H. J., \& Rubin, I. S. (2012). Qualitative interviewing: The art of hearing data (3rd ed.). Thousand Oaks, CA: Sage Publications. Retrieved from: https://www.amazon.com/Qualitative-Interviewing-ArtHearing-Data/dp/1412978378.

101. Saldana, J. (2016). The coding manual for qualitative researchers (3rd ed.). Thousand Oaks, CA: Sage Publications. Retrieved from: https://www.academia.edu/11310253/The_coding_manual_for_qualitative_researchers.

102. Santomier, J.P., Hogan, P.I., \& Kunz, R. (2016). The 2012 London Olympics: innovations in ICT and social media marketing. Innovation, 18(3), 251-269. DOI: 10.1080/14479338.2016.1237305.

103. Scuotto, V., Del Giudice, M., della Peruta, M.R., \& Tarba, S. (2017). The performance implications of leveraging internal innovation through social media networks: an empirical verification of the smart fashion industry. Technology Forecasting Social Change. 120, 184-194. https://doi.org/10.1016/j.techfore.2017.03.021.

104. Simkin, L., \& Dibb, S. (2013). Social media's impact on market segmentation and CRM. Journal of Strategic Marketing, 21(5), 391-393. https://doi-org.ezp.waldenulibrary.org/10.1080/0965254X.2013.801598.

105. Sinkovics, R., \& Alfoldi, E. (2012). Progressive Focusing and Trustworthiness in Qualitative Research. Management International Review, 52, 817-845. Retrieved from: https://link.springer.com/article/10.1007/s11575-012-0140-5

106. Singh, S. (2017). Marketing analytics is critical, but is data being left out? Gulf Marketing Review, 1.

107. Smilansky, O. (2015). Big data for big profits. CRM Magazine, 19(10), 28-31. Retrieved from: Business Source Complete, Ipswich, MA. https://www.ebsco.com/products/research-databases/business-sourcecomplete.

108. Steiger, D., Matzler, K., Chatterjee, S., \& Ladstaetter-Fussenegger, F. (2012). Democratizing strategy: how crowdsourcing can be used for strategy dialogues. California Management Review, 54(4), 44-69. https://doi.org/10.1525/cmr.2012.54.4.44.

109. Sutton, J., \& Austin, Z. (2015). Qualitative research: Data collection, analysis, and management. The Canadian Journal of Hospital Pharmacy, 68, 226-231. doi:10.4212/cjhp.v68i3.1456.

110. Trefler, A. (2014). Big data: Focusing on customer Boost growth. Chain Drug Review, 36(13), 46.

111. Tse, Y. K., Loh, H., Ding, J., \& Zhang, M. (2018). An investigation of social media data during a product recall scandal. Enterprise Information Systems, 12(6), 733-751. 10.1080/17517575.2018.1455110.

112. Vickers, M. (2017). Do you know your customers' generation? CRM Magazine, 21(4), 8. Retrieved from: https://www.destinationcrm.com/Articles/ReadArticle.aspx?ArticleID=117173.

113. Walaski, P. (2013). Social Media. Professional Safety, 58(4), 40-49. http://search.proquest.com/docview/1331594111? accountid=13380. 
114. Webb, S. H., \& Roberts, S. J. (2016). Communication and social media approaches in small businesses. Journal of Marketing Development \& Competitiveness, 10(1), 66-79. Retrieved from: https://searchebscohost-com.ezp.waldenulibrary.org/login.aspx ?direct=true\&db=bth\&AN=131724593\&site=ehostlive\&scope $=$ site.

115. Woodside, A. G. (2010). Bridging the chasm between survey and case study research: Research methods for achieving generalization, accuracy, and complexity. Industrial Marketing Management, 39(1), 64-75. doi: 10.1016/j.indmarman.2009.03.017.

116. West, S. (2017). Confronting negative narratives: The challenges of teaching professional social media use. Business \& Professional Communication Quarterly, 80(4), 409-425. doi: $10.117 / 2329490617723118$.

117. White, J., \& Drew, S. (2011). Collecting data or creating meaning? Qualitative Research Journal, 11(1), 3-12. doi:10.3316/ARJ1101003.

118. White, D. E., Oelke, N. D., \& Friesen, S. (2012). Management of a large qualitative data set: Establishing trustworthiness of the data. International Journal of Qualitative Methods, 11(3), 244-258. Retrieved from: http://ejournals.library.ualberta.ca/index.php/IJQM/article/view/9883.

119. Xiang, Z., Du, Q., Ma, Y., \& Fan, W. (2017). A comparative analysis of major online review platforms: Implications for social media analytics in hospitality and tourism. Tourism Management, 58(C), 51-65. doi:10.1016/j.tourman.2016.10.001.

120. Yin, R. (2011). Applications of case study research: Chapter one. Thousand Oaks, California: Sage Publications. Retrieved from: https://www.amazon.com/Applications-Case-Study-ResearchRobert/dp/1412989167.

121. Yin, R. (2014). Applications of case study research: New Edition. Thousand Oaks, California: Sage Publications. Retrieved from:https://edisciplinas.usp.br/pluginfile.php/1742025/mod_resource/content/1/How\%20to\%20know\% 20whether\%20and $\% 20$ when $\% 20$ to $\% 20$ use $\% 20$ the $\% 20$ case $\% 20$ study $\% 20$ as $\% 20 \mathrm{a} \% 20$ reserach $\% 20$ meth od.pdf.

122. Yen, C. (2016). How to unite the power of the masses? Exploring collective stickiness intention in social network sites from the perspective of knowledge sharing. Behaviour \& Information Technology, 35(2), 118-133. doi:10.1080/0144929X.2015.1105297.

123. Yuu, S., Xiaozhu, L., Yung Kyun, C., \& Sukki, Y. (2018). Narrative transportation and paratextual features of social media in viral advertising. Journal of Advertising, 47(1), 83-95. doi:10.1080/00913367.2017.1405752.

124. Zahoor, S. Z., \& Qureshi, I.H. (2017). Social Media Marketing and Brand Equity: A Literature Review. IUP Journal of Marketing Management, 16(1), 47-64. Retrieved from: https://www.researchgate.net/publication/331132272_Social_media_marketing_and_brand_equity_A_L iterature_review. 